\title{
A Structural Conformation Study of Aquatic Humic Acid
}

\author{
Luiz F. Zara, ${ }^{*, a}$ André H. Rosa, ${ }^{b}$ Ilda A. S. Toscano ${ }^{c}$ and Julio C. Rocha ${ }^{d}$ \\ ${ }^{a}$ Universidade Católica de Brasília, Q.S. 07, Lote 01, EPCT, 72030-170 Brasília-DF, Brazil \\ ${ }^{b}$ Departamento de Engenharia Ambiental, Universidade Estadual Paulista, Av. 3 de Março, 511, 18087-180 \\ Sorocaba-SP, Brazil \\ ${ }^{c}$ Departamento de Química, Universidade Federal da Paraíba 58059-900 João Pessoa-PB, Brazil \\ ${ }^{d}$ Instituto de Química, Universidade Estadual Paulista, 14800-900 Araraquara-SP, Brazil
}

\begin{abstract}
No presente trabalho foram extraídas substâncias húmicas aquáticas através do uso da resina adsorvente XAD 8, e a fração ácida separada por acidificação. Depois da purificação com resina Hyphan e diálise, os ácidos húmicos aquáticos foram caracterizados por espectroscopia no infravermelho com transformada de Fourier e análise elementar. A influência das concentrações dos ácidos húmicos e eletrólitos, pH e tempo de complexação ácido húmicometal sobre a conformação estrutural foi investigada através de estudos de espectroscopia UVVis, empregando a equação sugerida por Doty e Steiner. Os resultados indicam que a macromolécula flexível do ácido húmico assume uma forma condensada em valores de $\mathrm{pH}$ ácidos e alcalinos. Outros fatores favorecendo formas condensadas são tempos de complexação mais longos, e altas concentrações de ácidos húmicos e eletrólitos. Assim, considerando a forte influência dos parâmetros investigados na conformação estrutural da macromolécula húmica, podemos concluir que estudos usando espectroscopia UV/Vis para determinar a concentração, aromaticidade e grau de humificação dos ácidos húmicos aquáticos, requerem condições rigorosamente controladas para garantir uma correta interpretação dos resultados analíticos.
\end{abstract}

In the present work, aquatic humic substances (HS) were extracted by use of adsorbent XAD 8 and the acid humic fraction $(\mathrm{AH})$ was separated throught acidification. After being purified by Hyphan resin and dialyze, the aquatic AH was characterized using Fourier-transform infrared spectroscopy and elemental analysis. The influence of the aquatic HA and electrolyte concentrations, $\mathrm{pH}$ and aquatic AH-metal complexation time on the conformation was investigated using UV/Vis spectroscopic studies, employing the equation suggested by Doty and Steiner. The results indicated that the acid humic flexible macromolecule assumes a condensed form at acid and alkaline $\mathrm{pH}$. Other factors favoring condensed conformations are longer metal complexation time ("ageing") and higher aquatic $\mathrm{AH}$ and electrolyte concentrations. Thus considering the strong influence of the investigated parameters in the structural conformation of the humic macromolecule, we conclude that studies using UV/Vis spectroscopy to estimate the concentration, aromaticity, humification degree of the aquatic $\mathrm{AH}$ and so on, require rigorous control over the experimental conditions employed to provide a correct interpretation of the analytical results.

Keywords: aquatic humic acid, degree of condensation, UV/Vis spectroscopy

\section{Introduction}

Humic substances (HS) are products of the transformation of organic matter by the action of mycrobes and enzymes presents both in soil and water. They may be defined as a mixture of high molecular weight

*e-mail: zara@pos.ucb.br macromolecules (0.500-100 kDalton) of natural origin. ${ }^{1}$ The definition of aquatic HS is based on chromatographic extraction methods. Thurman and Malcolm, ${ }^{2}$ gave the name aquatic $\mathrm{HS}$ to the non-specific amorphous part of HS, consisting of dissolved organic carbon (DOC), at $\mathrm{pH}$ 2.0, that is adsorbed on to XAD-8 columns with a high distribution coefficient. Owing to the variability of the original organic material and the large number of different 
reactions that may occur during its degradation, it is not easy to suggest precise structural formulae for the HS. Nevertheless, it is thought that most HS consist of hydrophobic acids with highly oxygenated functional groups able to interact with heavy metal ions in aquatic systems. $^{3}$

The fraction of aquatic HS insoluble at $\mathrm{pH}<2$ is defined as aquatic humic acids (HA), whose molecular weights are in the range 0.003 to $0.100 \mathrm{kDalton}$. The elemental composition of aquatic HA in this range is of $54-59 \% \mathrm{C}, 3-6 \% \mathrm{H}, 33-38 \% \mathrm{O}, 0.8-4 \% \mathrm{~N}$ and $0.1-1 \%$ S. ${ }^{3,4}$

The structural conformation of the macromolecules depends on the extendedness of this "belt", pH, charge density, degree of ionization of the acid groups, ionic strength and concentration of humic substances, as well as on hydrogen bond formation and intramolecular rearrangements. ${ }^{5-7}$

The scattering of monochromatic light in a dilute solution of macromolecules or colloidal particles is closely related to its weight, size and interactions of the particles in solution. However, according to Doty and Steiner, ${ }^{8}$ similar information can be derived from difference spectroscopy (comparison of the absorbances at distinct wavelengths), using their formula:

$\frac{-d \log A}{d \log \lambda}=4-\beta$

where $\mathrm{A}$ is the absorbance of the solution, $\lambda$ the wavelength of transmitted light, $\beta$ is directly proportional to $b / \lambda^{0}, b$ is the largest dimension of the particle and $\lambda^{0}$, the wavelength of incident light.

Chen et al. ${ }^{9}$ using absorbance of a fulvic acid solution with different average molecular weights in 465 and 665 $\mathrm{nm}$ shows that the Doty and Steiner's, ${ }^{8}$ theory can be applicant to humic substances in dilute solution. Therefore the quantity $\beta$ can be directly related to the level of macromolecular aggregation, with higher values indicating a more aggregated humic macromolecule.

Investigations of the humic substances structural aggregation are important because its structure influences on the properties of the humic material. For example, on its capacity to react with metals and the stability of the aquatic HS-metal ion species formed. ${ }^{10}$

The aim of this work is to investigate the influence of the $\mathrm{pH}$, aquatic $\mathrm{HA}$ and electrolyte concentrations, and aquatic HA-metal complexation time on the conformation of the aquatic humic acid using UV/Vis spectroscopy studies, based on the Doty and Steiner's theory. ${ }^{8}$

\section{Experimental}

\section{Reagents and materials}

(All chemicals used were of high purity). Solutions of hydrochloric acid (30\% v/v), nitric acid (65\% v/v) and sodium hydroxide were prepared with high-purity water (Millipore Milli-Q). The resin XAD 8 p.a. (Serva Feinbiochimica), necessary for isolation of aquatic humic substances, was prepurified by successive soaking with 0.5 mol L-1 $\mathrm{HCl}, 0.5 \mathrm{~mol} \mathrm{~L}^{-1} \mathrm{NaOH}$ and methanol p.a. (24 h each). ${ }^{11}$ Cellulose Hyphan used for the removal of heavy metals from aquatic HS concentrate was applied according to recommendations given in Danielsson. ${ }^{12}$ The cellulose sorbent cellulose phosphate (CellPhos) used in this study for the separation of labile metal fractions in the aquatic HA was functionalized according to Ford and Hall. ${ }^{13}$ This collector has a surface area of $1.94+0.06 \mathrm{~m}^{2} \mathrm{~g}^{-1}$ and $1.3+0.09 \mathrm{~mol} \mathrm{~g}^{-1}$ of immobilized phosphate groups.

\section{Aquatic HA isolation, separation and purification}

The aquatic HS under study was isolated from a humicrich water sample collected from the Itapanhaú river, which flows through the Ecological Reserve of the "Parque Estadual da Serra do Mar" located in São Paulo State, Brazil. For this purpose, 20 liters of surface water (about $25 \mathrm{~cm}$ below the water surface) were on-site filtered through $0.45 \mu \mathrm{m}$ cellulose-based membranes and acidified with concentrated $\mathrm{HCl}$ to $\mathrm{pH} 2.0$ with $10 \mathrm{~mol} \mathrm{~L}^{-1} \mathrm{HCl}$ (suprapur, Merck). Afterwards, the aquatic HS were conventionally isolated on the XAD 8 collector following the recommendations of Malcolm ${ }^{12}$. After elution with $0.1 \mathrm{~mol} \mathrm{~L}^{-1} \mathrm{NaOH}(100 \mathrm{~mL})$, the concentrate obtained was neutralized to $\mathrm{pH} 7.0$ with $2.0 \mathrm{~mol} \mathrm{~L}^{-1} \mathrm{HCl}$ solution. In order to remove the metals naturally present in the aquatic $\mathrm{HS}, 50 \mathrm{~mL}$ of this concentrate was mechanically stirred for $24 \mathrm{~h}$ with $1 \mathrm{~g}$ of cellulose Hyphan at $\mathrm{pH}$ 8.0. ${ }^{14}$ Next, the aquatic HA fraction was precipitation at $\mathrm{pH} 1.5$, with $6 \mathrm{~mol} \mathrm{~L}^{-1} \mathrm{HCl}$ solution, and separated by centrifugation (4000 rpm) after 24 hour, purified by dialyze, ${ }^{15}$ and lyophilized.

\section{Characterizations}

The determination of DOC contained in the aquatic humic substance was carried out by catalytic combustion in an oxygen stream on an Schimadzu TOC 2000 Analyser. ${ }^{16}$ The elemental composition (CHN) of the aquatic HA was determined using a Perkin-Elmer 240-C elemental analyzer. The Fourier-transform infrared 
spectrum of aquatic HA was recorded using a Nicolet 730 SX-FT spectrometer. The pellets was prepared with $8 \mathrm{mg}$ of aquatic HA per $100 \mathrm{mg}$ of $\mathrm{KBr}^{17}$

\section{Structural aggregation study}

UV/Vis spectroscopy. The influence of the $\mathrm{pH}$ (3-11), aquatic HA (0.04-1.02 $\left.\mathrm{mg} \mathrm{L}^{-1}\right)$ and electrolyte (0-0.32 mg $\left.\mathrm{L}^{-1}\right)$ concentrations, and aquatic HA-metal complexation time (0.25-130 hour) on the conformation of the aquatic humic acid macromolecule were obtained by UV/Vis spectrometry at 465 and $665 \mathrm{~nm}$, using a twin-beam Hitachi UV-2000 spectrometer.

Complexation time. The aquatic HA sample used in the investigation of the complexation time was spiked with copper as follows: $5.0 \mu \mathrm{g} \mathrm{Cu}$ (II) ions were added to 20 $\mathrm{mL}$ of $0.5 \mathrm{mg} \mathrm{L}^{-1}$ aquatic HA solution in $0.01 \mathrm{mg} \mathrm{L}^{-1}$ $\mathrm{NaCl}$ (buffered at $\mathrm{pH} 5.0$ ), and, after adjust of volume to $25 \mathrm{~mL}$ with $0.01 \mathrm{mg} \mathrm{L}^{-1} \mathrm{NaCl}$ solution, mechanically stirred for $130 \mathrm{~h}$. After pre-set complexation time (2-120 h), $80 \mathrm{mg}$ of CellPhos was added in $10.0 \mathrm{~mL}$ of aquatic AH solution contend metal spiking and stirred for $24 \mathrm{~h}$. The ion-exchange was filtered though filter paper $(2 \mathrm{~cm}$ diameter) previously cleaned with $1 \mathrm{~mol} \mathrm{~L}^{-1} \mathrm{HCl}$. Paper and resin were transferred to small flasks and extracted for $1 \mathrm{~h}$ with $3.0 \mathrm{~mL}$ of $2.0 \mathrm{~mol} \mathrm{~L}{ }^{-1} \mathrm{HCl}$ suprapur. ${ }^{18}$ After centrifugation (4000 rpm) of the eluate, the metal contained was determined by ICP-AES, using a Thermo Jarrel Ash-CID-DUO spectrometer, according to the experimental condition give in Table 1 .

Table 1. Operating parameter for the ICP-AES determinations

\begin{tabular}{ll}
\hline Incident power & $1.5 \mathrm{KW}$ \\
Plasma air flow-rate & $15 \mathrm{~L} \mathrm{~min}^{-1}$ \\
Nebulizer air flow-rate & $1.2 \mathrm{~L} \mathrm{~min}^{-1}$ \\
Auxiliary air flow-rate & $0.5 \mathrm{~L} \mathrm{~min}^{-1}$ \\
Sample flow-rate & $2.4 \mathrm{~mL} \mathrm{~min}^{-1}$ \\
Analytical line & 327.396 \\
\hline
\end{tabular}

\section{Results and Discussion}

\section{Aquatic HA characterization}

The Table 2 shows the complementary information about the studied aquatic humic substance.

The aquatic HA in the sample was found to contain average $51.76 \% \mathrm{C}, 4.32 \% \mathrm{H}$ and $2.13 \% \mathrm{~N}$, in agreement with previously published data. ${ }^{19}$ In the infrared absorption spectrum of the humic acid, a wide band was observed in the region of $3430 \mathrm{~cm}^{-1}$, attributed to stretching of alcoholic, phenolic and/or carboxylic $\mathrm{OH}$ bonds, while absorption due
Table 2. Complementary information about the studied aquatic humic substances

\begin{tabular}{ll}
\hline Origin & Rio Itapanhaú \\
$\mathrm{pH}$ & 5.0 \\
Conductivity & $58 \mu \mathrm{S} \mathrm{cm}-1$ \\
Temperature & $25{ }^{\circ} \mathrm{C}$ \\
DOC & $4.5 \mathrm{mg} \mathrm{mL}^{-1}$ \\
Original aquatic humic substance & $9.0 \mathrm{mg} \mathrm{mL}^{-1}$ \\
\hline
\end{tabular}

to carboxylic CO stretching was seen in the $1160 \mathrm{~cm}^{-1}$ region. An absorption band at $2940 \mathrm{~cm}^{-1}$ is caused by aliphatic $\mathrm{CH}$ stretching, while another at $1718 \mathrm{~cm}^{-1}$ is assigned to $\mathrm{C}=\mathrm{O}$ stretching in ketones and/or carboxylic acids. A medium-width band around $1620 \mathrm{~cm}^{-1}$ is associated with $\mathrm{C}=\mathrm{C}$ stretching in alkenes and/or aromatics. This infrared absorption spectrum is consistent with those found in the literature..$^{20-22}$

\section{Structural aggregation study}

In the literature we found three different viewpoints about sizes and shapes of humic substances in solution. One suggest that macromolecule humic assume random coil conformation, a second proposed that HS are molecular association of relatively small molecules held together by weak interaction force; a third considered that HS appears in solution as micelle or "pseudomicellar" structures. ${ }^{23-25}$ The ratio of the optical densities of a dilute solution at two different wavelengths, 465 and $665 \mathrm{~nm}$ $\left(\mathrm{E}_{4} / \mathrm{E}_{6}\right)$ is used to characterize humic acids. The $\mathrm{E}_{4} / \mathrm{E}_{6}$ ratio indicates the average level of structural condensation of the molecules in solution. ${ }^{13}$ Applying the ratio $\mathrm{E}_{4} / \mathrm{E}_{6}$ in Doty and Steiner formula, ${ }^{8}$ we have:

$\frac{-\log E_{4}-\log E_{6}}{\log 465-\log 665}=4-\beta$

Rearranging, $4-6.435\left(\mathrm{E}_{4} / \mathrm{E}_{6}\right)=\beta$

The quantity $\beta$ can be directly related to the level of condensation of the macromolecular structure, higher values indicating a more condensed conformation of the humic macromolecule.

In Figure 1, $\beta$ is the highest, at acid $\mathrm{pH}$ indicating more condensed macromolecules. A second maximum is observed at alkaline $\mathrm{pH}$. At low $\mathrm{pH}$, interactions due to hydrogen bonds, van der Waal's forces and $\pi$-orbitals in conjugated aromatic rings within the humic macromolecule, ${ }^{7}$ favor a more aggregated conformation of the aquatic HA macromolecules and intermolecular association. Moreover, intermolecular interactions may 
induce the formation of dipoles through the delocalization of aromatic-ring $\pi$-electrons, thus favoring the aggregation of the macromolecule humic. ${ }^{24}$ At high $\mathrm{pH}$, the charge density on the macromolecule rises, owing to increased ionization of the acid groups. However, the counter-ions in solution $\left(\mathrm{Na}^{+}\right)$minimize the charge potential on the humic polyelectrolyte, causing na expansion of the eletric duble layer, resulting in repulsion and dispersion of the particle. In this condition the humic macro molecule assumes an "micelle-like" structure. The humic substance have amphiphilic properties in which the molecules have hydrophobic (nonpolar) and hydrophilic (polar) parts, which can induce the "micelle-like" structure formation in solution. ${ }^{25}$ The Figure 1 shows the variation value $\beta$ of the 1.9 units in the acid region ( $\mathrm{pH} \mathrm{3-7),} \mathrm{while} \mathrm{in} \mathrm{the}$ alkaline region $(\mathrm{pH} 7-11)$ this variation is only 0.8 unites. This indicates the strong influence of alkaline region in the charge repulsion, favouring the extended conformation.

Lower values of $\beta$ are found at neutral $\mathrm{pH}$, leading to the conclusion that, in this case, the flexible humic macromolecule apparently adopts an extended form, because of intramolecular charge repulsions associated with increased charge density on the macromolecule.

In Figure 2 the $\mathrm{b}$ values are plotted as a function of aquatic HA concentration, and the latter is seen to exert a

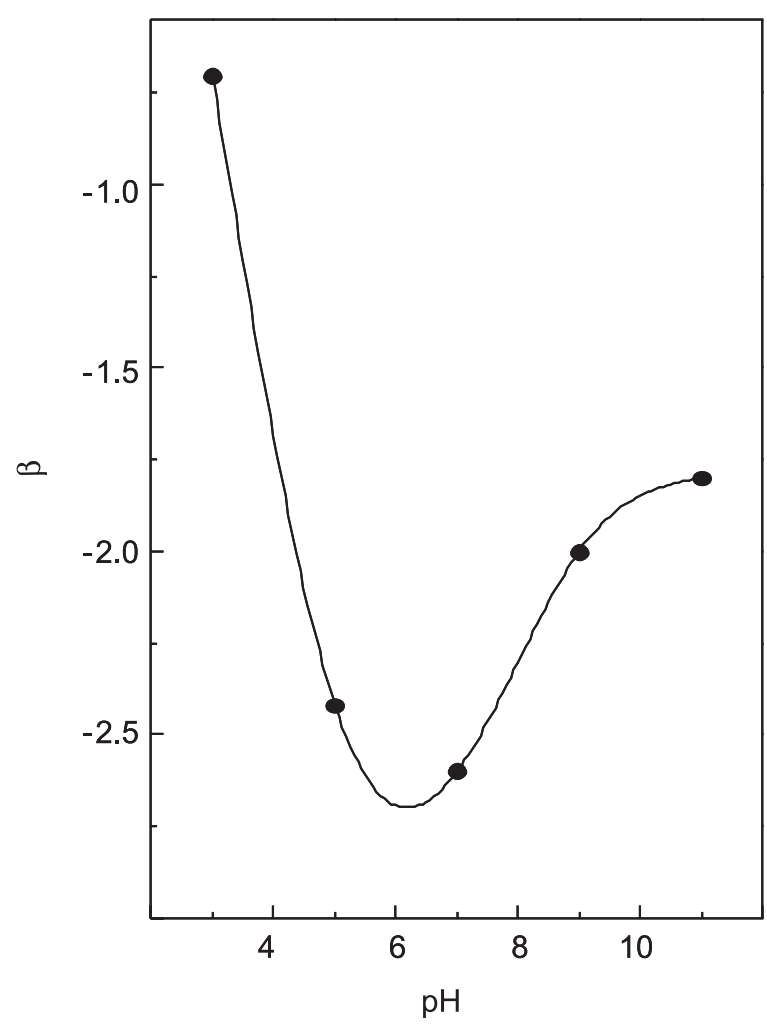

Figure 1. Influence of the $\mathrm{pH}$ on the parameter $\beta$ in aquatic humic acid solution. Condition: concentration of aquatic HA: $0.4 \mathrm{mg} \mathrm{L}^{-1}$ and $\mathrm{NaCl}$ concentration: $0.01 \mathrm{mg} \mathrm{L}^{-1}$. strong influence in dilute solution. This effect may be due to a reduction, in dilute solution, of the intramolecular repulsion between negative charges arising from ionization of the acid groups, leading to a more condensed structure. However, the effect on $\beta$ caused by concentration of aquatic $\mathrm{AH}$ rises from 0.2 to $1.02 \mathrm{mg} \mathrm{L}^{-1}$ is approximately 9 times smaller that observed in the rise in concentration from 0.08 to $0.2 \mathrm{~mol} \mathrm{~L}^{-1}$. This fact is probably due to the micelle formation. These results evidence that aggregation greed of humic macromolecule is more strongly influenced by intra-/intermolecular interaction that by micelle formation, according to data observed from these $\mathrm{pH}$ study.

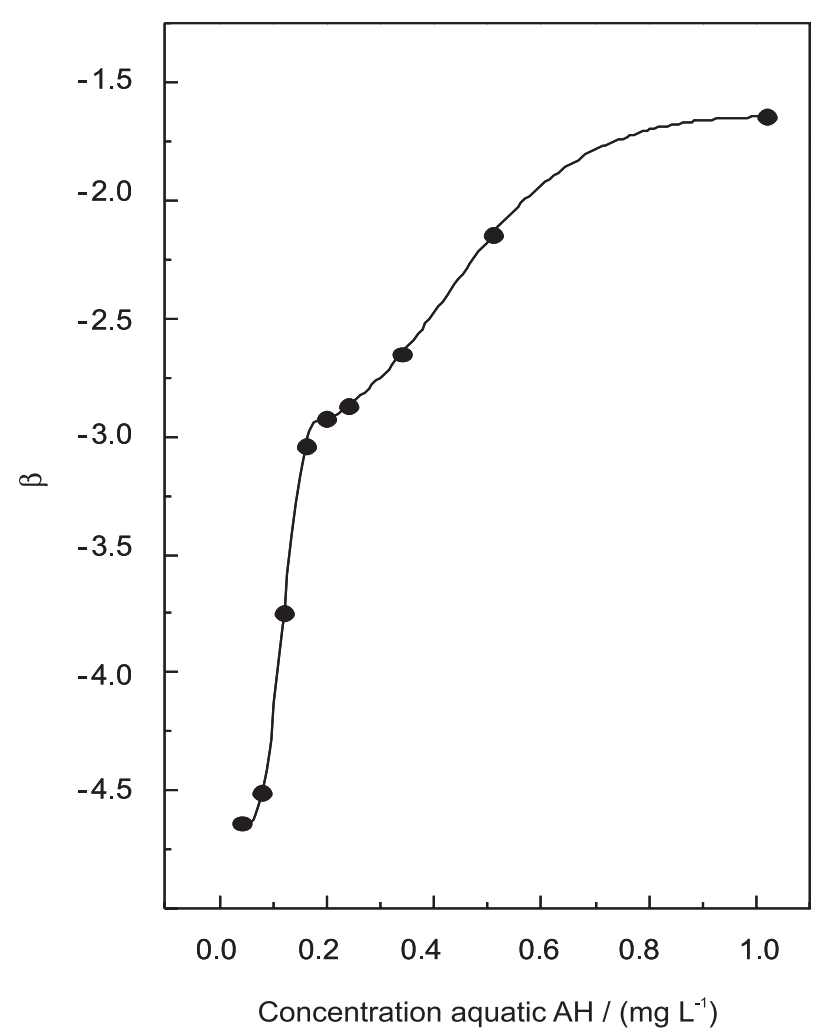

Figure 2. Influence of the aquatic humic acid concentration on the parameter $\beta$. Condition: $\mathrm{pH}: 5.0$ and $\mathrm{NaCl}$ concentration: $0.01 \mathrm{mg} \mathrm{L}^{-1}$.

In the environment, the aquatic HA-metals interactions occur over a relatively long time (ageing process) affecting the lability of metal fractions complexed by aquatic $\mathrm{AH}$. Figure 3 shows that after a complexation time of $48 \mathrm{~h}$ the $\mathrm{Cu}(\mathrm{II})$ ion recovery is reduced from $73 \%$ to $54 \%$. In general, metals complexed with the most external groups of the humic macromolecule react preferentially with the functional groups of the resin. Consequently, the metal remains complexed for a long time, probably due to transformation process and inner rearrangement. As time increase, less accessible binding sites of substances humic may be occupied, and a change of metal ions from weaker to stronger binding sites may take place. ${ }^{10,14}$ 
The increase invalue of $\beta$ with the complexation time, seen in Figure 3, indicates that aggregation greed of macromolecule is influenced by rearrangements of the metal in the humic macromolecule during "ageing". It is reasonable to assume that these rearrangements diminish intramolecular repulsive forces, favoring the condensed conformation by allowing more intramolecular interactions. As this takes place, the complexation sites become less accessible to ion exchange processes. This may explain the large effect that complexation time has on the relative decrease in the lability of metal ions..$^{26,27}$

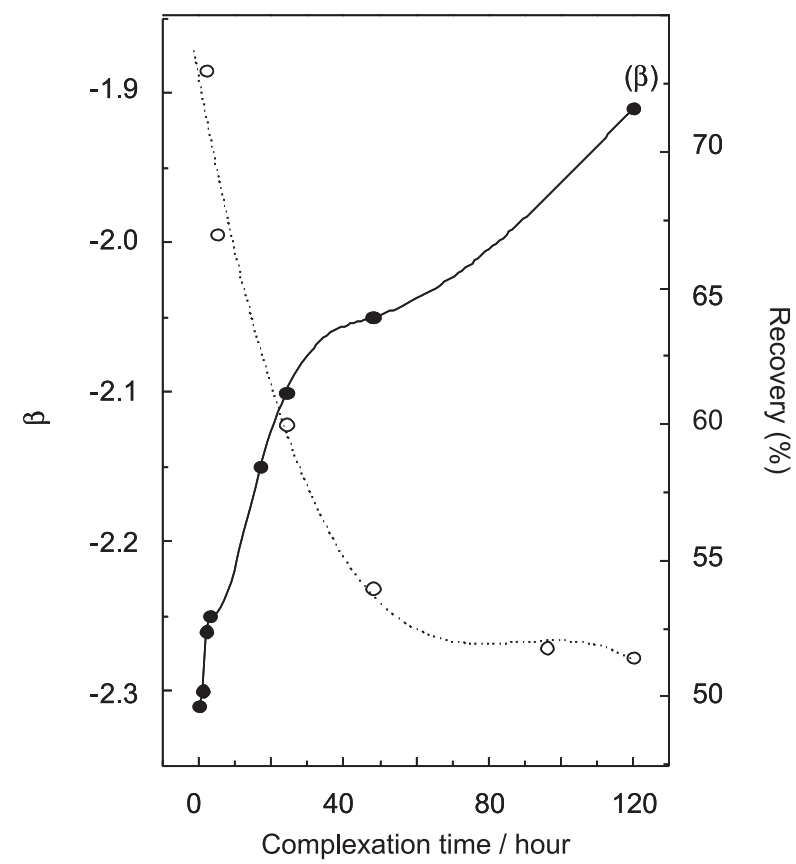

Figure 3. Influence of aquatic HA-metal complexation time ("ageing") on the parameter $\beta$. Condition: aquatic $\mathrm{HA}: 0.4 \mathrm{mg} \mathrm{L}^{-1}, \mathrm{NaCl}$ concentration: $0.01 \mathrm{mg} \mathrm{L}^{-1}, \mathrm{pH}: 5.0$ and $5.0 \mu \mathrm{g} \mathrm{Cu}(\mathrm{II})$ ion.

Variation of the sodium chloride concentration has an exponential effect on the value of $b$, as shown in Figure 4. In dilute solution at appropriate $\mathrm{pH}$, fulvic and humic acids and their alkali metal salts are considered to be real colloidal solutions, showing the properties of both polyelectrolyte and surfactant solution. Tombácz and Regdon, ${ }^{25}$ using humic acid extracted from brown coal reported that Na-humate solutions had a very weak emulsifying effect. Therefore, it is reasonable to assume that the micelle formation increase with the sodium chloride concentration. This effect is similarity to the observed on alkaline region in the Figure 1.

\section{Conclusions}

The aquatic humic acid macromolecule can be classified as a flexible polyelectrolyte whose structural conformation depends on conditions in the medium, such

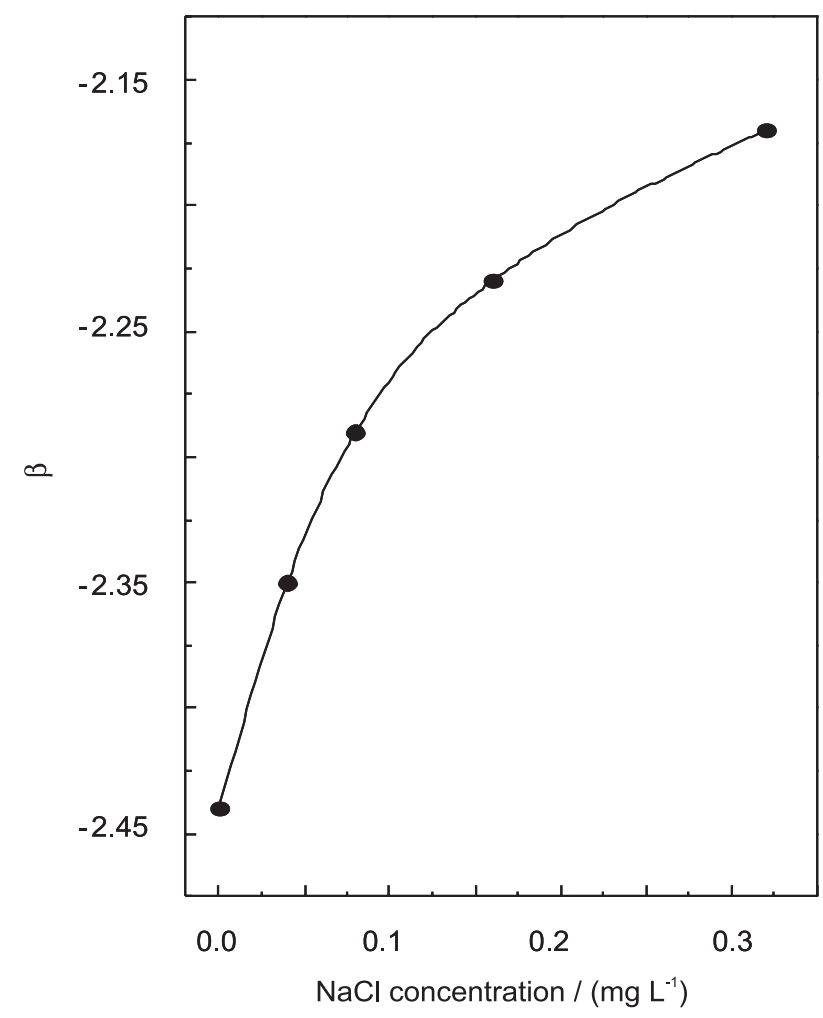

Figure 4. Influence of sodium chloride concentration on the parameter $\beta$. Condition: aquatic HA: $0.4 \mathrm{mg} \mathrm{L}^{-1}$ and $\mathrm{pH}$ 5.0.

as $\mathrm{pH}$, concentration of AHA and electrolyte concentration. Thus, studies using visible light absorption to estimate the concentration, aromaticity, extent of humification of the AHA and so on, require rigorous control over the experimental conditions employed, to enable a correct interpretation of the analytical results.

Moreover, it has been shown that longer complexation times "ageing" favor the condensed conformation of the macromolecule, possibly lowering the relative lability of the metal ions complexed by the aquatic humic acid.

\section{Acknowledgments}

The financial support for this work by CAPES, CNPq and FAPESP is gratefully acknowledged.

\section{References}

1. Aiken, G. R. In Humic Substances in Soil, Sediment and Water. Geochemistry, Isolation and Characterization; Aiken, G. R.; MacKnight, M. D.; Wershaw, R. L.; MacCarthy, P., eds.; John Wiley \& Sons: New York, 1985.

2. Thurman, E. M.; Malcolm, R. L.; Environ. Sci. Technol. 1981, $15,463$.

3. Huffman Jr., E. W. D.; Stuber, H. A. In Humic Substances in Soil, Sediment and Water. Geochemistry, Isolation and 
Characterization; Aiken, G. R.; MacKnight, M. D.; Wershaw, R. L.; Mac Carthy, P., eds.; John Wiley \& Sons: New York, 1985.

4. Schulten, H. R.; Fresenius J. Anal. Chem. 1995, 351, 62.

5. Swift, R. S. In Humic Substances II; Hayes, M. H. B.; MacCarthy, P.; Malcolm, R. L.; Swift, R. S., eds.; John Wiley \& Sons: New York, 1989.

6. Hayes, M. H. B. In Humic Substances in Soil, Sediment and Water. Geochemistry, Isolation and Characterization; Aiken, G. R.; MacKnight, M. D.; Wershaw, R. L.; MacCarthy, P., eds.; John Wiley \& Sons: New York, 1985.

7. Ghosh, K.; Schnitzer, M.; Soil Sci. 1980, 129, 266.

8. Doty, P.; Steiner, R. F.; J. Chem. Phys. 1950, 18, 1211.

9. Chen, Y.; Senesi, N.; Schnitzer, M.; Soil Sci. Soc. Am. J. 1977, 41, 352.

10. Burba, P.; Fresenius' J. Anal. Chem. 1994, 348, 301.

11. Malcolm, R. L. In Humic Substances In The Aquatic And Terrestrial Environment; Allard, B.; Boren, H.; Grimvall, A., eds.; Springer: Berlin, 1991.

12. Danielsson, L. G.; Water Res. 1992, 16, 179.

13. Ford, F. M.; Hall, W. P.; US pat. 2,482,755 1949.

14. Rocha, J. C.; Toscano, I. A. S.; Cardoso, A. A.; J. Braz. Chem. Soc. 1997, 8, 239.

15. Town, R. M.; Powell, H. K. J.; Anal. Chim. Acta 1992, $256,81$.

16. Wangersky, P. J.; Mar. Chem. 1993, 41, 61.
17. Pang, L. S. K.; Vassallo, A. M.; Wilson, M. A.; Org. Geochem. 1990, 16, 853.

18. Rocha, J. C.; Toscano, I. A. S.; Burba, P.; Talanta 1997, 44, 69.

19. Senesi, N.; In Organic Substances in Soil and Water. Natural Constituents and Their Influences on Contaminant Behaviour; Beck, A. J.; Jones, K. C.; Hayes, M. H. B.; Mingelfrin, U., eds.; Royal Society of Chemistry: Cambridge, 1993.

20. Rocha, J. C.; Rosa, A. H.; Furlan, M.; J. Braz. Chem. Soc. 1998, 9, 51.

21. Rocha, J. C.; Sene, J. J.; Santos, A.; Toscano, I. A. S.; Zara, L. F.; J. Environ. Monit. 2000, 2, 39.

22. Celi, L.; Schnitzer, M.; Nègre, M.; Soil Sci. 1997, 162, 189.

23. Clapp, C. E.; Hayes, M. H. B.; Soil Sci. 1999, 164, 777.

24. Bartschat, B. M.; Cabaniss, S. E.; Morel, F. M. M.; Environ. Sci. Technol. 1992, 26, 284.

25. Tombácz, E.; Regdon, I. In Humic Substances in the Global Environment and Implications on Human Health; Senesi, N.; Miano, T. M., eds.; Elsevier: Amsterdam, 1994.

26. Burba, P.; Rocha, J. C.; Klockow, D.; Fresenius'J. Anal. Chem. 1994, 349, 800.

27. Sargentini Jr., É; Rocha, J. C.; Rosa, A. H.; Zara, L. F.; Santos, A.; Quim. Nova 2001, 24, 339.

Received: November 19, 2004 Published on the web: July 13, 2006

FAPESP helped in meeting the publication costs of this article. 